\title{
Peter Marker
}

\section{Skal tokammersystemet genindføres?}

\begin{abstract}
De ustabile parlamentariske forhold op gennem 1980'erne har fảet flere fremtradende politikere til at foreslä, at tokammersystemet genindføres i Danmark. Det vasentligste problem ved en sădan institutionel ændring vil givetvis vare, at tokammersystemet efter manges opfattelse er udemokratisk. Men det behover ikke at være tilfældet. Det afhænger af, hvordan forstekammeret sammensættes, og hvilken kompetence det tillagges i forhold til andetkammeret. Et demokratisk forstekammer valgt ud fra lige og almindelig valgret kunne indfores for at sikre adskillelsen mellem den lovgivende og den udøvende magt, og et forstekammer af foderalt tilsnit med sarreprasentation for amter og kommuner kunne muligvis give større narhed og responsivitet $i$ det politiske system.
\end{abstract}

\section{De politiske problemer}

Fra forskellig side er det i løbet af de seneste år blevet foreslået at genindføre tokammersystemet i Danmark. Med henvisning til behovet for en bedre kontrol med regeringen, og dermed en større åbenhed omkring EU-politikken foreslog Niels Helveg Petersen i februar 1992, at Folketingets Markedsudvalg blev erstattet af et direkte folkevalgt førstekammer' med 17 medlemmer og faste valgperioder på 4-5 år. Udover at lette arbejdspresset, skulle førstekammeret sikre en bedre kontrol med regeringen og dermed større offentlighed omkring EU-politiken (Berlingske Tidende, 12.02.92). Tilsvarende har EUkommissær Henning Christophersen fremsat forslag om at genindføre tokammersystemet for at opnå større politisk stabilitet og "give personer med en anden baggrund end de nuværende politikere mulighed for at bidrage med deres erfaring ved lovgivningsarbejdet". Endvidere kunne et førstekammer sikre amter og kommuner større indflydelse på lovgivningen (Christophersen, 1989: 119). Begge disse forslag må ses som en reaktion på de grundlæggende forandringer, det danske politiske system har gennemgået siden vedtagelsen af den nugældende grundlov i 1953. Forandringerne kan sammenfattes i fire hovedpunkter, 1) stabilitet/kontinuitet, 2) grundighed/kvalitet, 3) nærhed/responsivitet og 4) offentlighed/åbenhed.

For det første er det tidligere stabile firepartisystem brudt sammen. Ved folketingsvalget i 1973 blev de nogenlunde faste samarbejdsrelationer mellem de gamle partier erstattet af et fragmenteret og opsplittet partisystem. Siden da har der været afholdt folketingsvalg godt hvert andet år, og de skiftende mindretalsregeringer har haft svært ved at gennemføre en konsekvent politik. Denne ustabile politiske situation har medvirket til at svække befolkningens tiltro til de folkevalgte politikere (Petersen, 1992: 19ff).

For det andet har de etablerede politiske institutioner mistet autoritet og legitimitet, fordi den politiske dagsorden ikke længere kun sættes af partierne, men også af enkeltsagsbevægelser og især af medierne. Det har i flere tilfælde medført forhastet lovgivning, som har fảet utilsigtede og ofte også uheldige konsekvenser. En anden medvirkende årsag til den manglende grundighed ved lovgivningsarbejdet er det stigende antal sager, politikerne skal tage stilling til. 


\title{
Peter Marker
}

\section{Skal tokammersystemet genindføres?}

\begin{abstract}
De ustabile parlamentariske forhold op gennem 1980'erne har fảet flere fremtradende politikere til at foreslä, at tokammersystemet genindføres i Danmark. Det vasentligste problem ved en sădan institutionel ændring vil givetvis vare, at tokammersystemet efter manges opfattelse er udemokratisk. Men det behover ikke at være tilfældet. Det afhænger af, hvordan forstekammeret sammensættes, og hvilken kompetence det tillagges i forhold til andetkammeret. Et demokratisk forstekammer valgt ud fra lige og almindelig valgret kunne indfores for at sikre adskillelsen mellem den lovgivende og den udøvende magt, og et forstekammer af foderalt tilsnit med sarreprasentation for amter og kommuner kunne muligvis give større narhed og responsivitet $i$ det politiske system.
\end{abstract}

\section{De politiske problemer}

Fra forskellig side er det i løbet af de seneste år blevet foreslået at genindføre tokammersystemet i Danmark. Med henvisning til behovet for en bedre kontrol med regeringen, og dermed en større åbenhed omkring EU-politikken foreslog Niels Helveg Petersen i februar 1992, at Folketingets Markedsudvalg blev erstattet af et direkte folkevalgt førstekammer' med 17 medlemmer og faste valgperioder på 4-5 år. Udover at lette arbejdspresset, skulle førstekammeret sikre en bedre kontrol med regeringen og dermed større offentlighed omkring EU-politiken (Berlingske Tidende, 12.02.92). Tilsvarende har EUkommissær Henning Christophersen fremsat forslag om at genindføre tokammersystemet for at opnå større politisk stabilitet og "give personer med en anden baggrund end de nuværende politikere mulighed for at bidrage med deres erfaring ved lovgivningsarbejdet". Endvidere kunne et førstekammer sikre amter og kommuner større indflydelse på lovgivningen (Christophersen, 1989: 119). Begge disse forslag må ses som en reaktion på de grundlæggende forandringer, det danske politiske system har gennemgået siden vedtagelsen af den nugældende grundlov i 1953. Forandringerne kan sammenfattes i fire hovedpunkter, 1) stabilitet/kontinuitet, 2) grundighed/kvalitet, 3) nærhed/responsivitet og 4) offentlighed/åbenhed.

For det første er det tidligere stabile firepartisystem brudt sammen. Ved folketingsvalget i 1973 blev de nogenlunde faste samarbejdsrelationer mellem de gamle partier erstattet af et fragmenteret og opsplittet partisystem. Siden da har der været afholdt folketingsvalg godt hvert andet år, og de skiftende mindretalsregeringer har haft svært ved at gennemføre en konsekvent politik. Denne ustabile politiske situation har medvirket til at svække befolkningens tiltro til de folkevalgte politikere (Petersen, 1992: 19ff).

For det andet har de etablerede politiske institutioner mistet autoritet og legitimitet, fordi den politiske dagsorden ikke længere kun sættes af partierne, men også af enkeltsagsbevægelser og især af medierne. Det har i flere tilfælde medført forhastet lovgivning, som har fảet utilsigtede og ofte også uheldige konsekvenser. En anden medvirkende årsag til den manglende grundighed ved lovgivningsarbejdet er det stigende antal sager, politikerne skal tage stilling til. 
Det voksende arbejdspres skyldes dels væksten i den offentlige sektor, dels det omfattende samarbejde mellem EU-landene (Christensen, 1992).

For det tredje har netop udvidelsen af det internationale samarbejde betydet, at en lang række vigtige politiske beslutninger er flyttet fra Folketinget til Ministerrådets møder i Bruxelles. Herved er afstanden mellem befolkningen og beslutningstagerne efter manges opfattelse blevet for stor, og vælgerne har derfor mistet tilliden til det politiske system. Der er med andre ord grænser for, hvor langt det repræsentative demokrati kan udstrækkes (se i øvrigt Dahl, 1989: 317ff). På denne baggrund er der opstået et ønske om større nærhed i det politiske system. Afgørelserne skal træffes så tæt på den enkelte borger som muligt, og samtidig skal der i videre omfang tages hensyn til lokale forhold.

Endelig har integrationen på europæisk plan for det fjerde betydet, at den politiske beslutningsproces er blevet mere lukket. Regeringen forhandler i Ministerrådet på grundlag af et mandat fra Folketingets Markedsudvalg. Men møderne i Markedsudvalget foregår bag lukkede døre, og Ministerrådets møder har indtil nu heller ikke været offentlige. De enkelte lande har for eksempel ikke pligt til at oplyse, hvordan de har stemt i en given sag. Desuden er EU-Kommissionens arbejde ikke undergivet den samme effektive kontrol, som de danske folketingsudvalg udøver over for centraladministrationen. Alt dette har rejst et krav om mere åbenhed og offentlighed om EU-politikken.

Hvis tokammersystemet skal genindføres, må formålet være at løse de nævnte problemer. Et førstekammer med længere valgperioder og vanskelig opløselighed kunne for eksempel give større stabilitet og kontinuitet i det politiske system, medens den dobbelte behandling af lovforslagene kunne sikre mere grundighed og kvalitet i lovgivningsarbejdet. Det må dog være en ubetinget forudsætning for en eventuel forfatningsændring, at tokammersystemet er foreneligt med de grundlæggende liberale, demokratiske principper, som den nuværende grundlov hviler på. Kun hvis det er tilfældet, kan det komme på tale at genindføre et førstekammer. Endvidere må det overvejes, om fordelene ved tokammersystemet er så store, at de i sig selv kan begrunde en grundlovsændring, eller om problemerne kunne løses ved at ændre de politiske procedurer i det nuværende etkammersystem.

\section{Tokammersystemet}

Tokammersystemet har sin oprindelse i England omkring år 1340, hvor den daværende rådsforsamling blev delt $\mathrm{i}$ et adeligt Overhus og et Underhus af valgte repræsentanter (Ross, 1946: 337ff). Et tilsvarende aristokratisk førstekammer blev indført i Frankrig i 1814 og kom til at danne forbillede for en lang række europæiske forfatninger i den første halvdel af 1800-tallet. Den politiske og okonomiske udvikling medførte imidlertid, at det feudalt-aristokratiske førstekammer mistede sin legitimitet, og med udgangspunkt i den belgiske forfatning fra 1831 indførtes i mange lande et folkevalgt førstekammer, der dog hvilede på en privilegeret valgret. Efterhånden som valgretten til de to kamre blev udvidet, bredte der sig en opfattelse af, at et etkammersystem i højere grad ville være i overensstemmelse med de demokratiske grundidéer. På 
denne baggrund afskaffedes førstekammeret i blandt andet New Zealand, Sverige og Danmark, medens tokammersystemet fortsat findes i alle forbundsstater, herunder USA og Tyskland. En helt særlig form for førstekammer findes i Irland, hvor medlemmerne udpeges af premierministeren, universiteterne og de største erhvervsorganisationer.

Førstekammeret har gennem tiderne været sammensat på forskellig måde og repræsenteret forskellige interesser i samfundet. Der er med andre ord tale om flere forskellige typer af førstekamre, som man må skelne mellem, når det skal vurderes, hvorvidt tokammersystemet er demokratisk eller ej. Overordnet kan man sondre mellem et aristokratisk, et konservativt, et elitistisk, et føderalt og et demokratisk førstekammer. ${ }^{2}$ Muligheden for at genindføre tokammersystemet i Danmark vil således afhænge af, hvilken type tokammersystem, der er tale om. Det er helt afgørende, hvad formålet med førstekammeret er, hvordan det sammensættes, og hvilken kompetence det $\mathrm{i}$ givet fald tillægges $\mathrm{i}$ forhold til andetkammeret. Man må derfor gøre sig klart, hvilke betingelser der skal stilles til valgret og valgbarhed, hvilken valgmåde der skal anvendes, og på hvilke punkter førstekammeret skal adskille sig fra andetkammeret med hensyn til valgperiodens længde og lignende. Alle disse aspekter af tokammersystemet gennemgås i det følgende ud fra den liberale demokratiske teori.

\section{Valgret og valgbarhed}

Sammensætningen af førstekammeret er først og fremmest afhængig af, hvem der har ret til at vælge eller udpege medlemmerne, og hvem der kan vælges eller udpeges. Den ældste type førstekammer er det aristokratiske, hvor medlemskabet enten er arveligt eller opnås ved kongelig udnævnelse. Sin mest udprægede form har det aristokratiske førstekammer haft i England, der var forbilledet for Montesquieu, da han begrundede, hvorfor adelen og aristokratiet bør sikres en særrepræsentation:

"In a state there are always some people who are distinguished by birth, wealth or honors; but if they were mixed among the people and if they had only one voice like the others, the commom liberty would be their enslavement. (...) Thus legislative power will be entrusted both to the body of the nobles and to the body that will represent the people" (Montesquieu, 1748: 160).

Medens den udøvende magt er forbeholdt kongen, mener Montesquieu, at både den almindelige befolkning og adelstanden har ret til særskilt repræsentation i den lovgivende forsamling. Det aristokratiske tokammersystem kan derfor ses som en videreførelse af det feudale samfunds adskillelse af befolkningen i forskellige stænder, og parlamentets todeling bliver herved en afspejling af datidens magtforhold mellem stænderne (jf. Mill, 1861: 514; Rasmussen, 1972: 41).

Det aristokratiske forstekammer strider helt klart mod det demokratiske folkesuverænitetsprincip. Den formelle ret til at træffe bindende beslutninger med virkning for hele samfundet tilkommer i et demokrati hele befolkningen, og det enkelte individ har ret til selv at deltage $i$ udformningen af de love og regler, vedkommende er undergivet. Denne suverænitet kan ifølge Rousseau 
hverken delegeres til andre eller afhændes. I modsætning hertil er monarkiske og aristokratiske styreformer netop kendetegnet ved, at suveræniteten enten ligger hos en enkelt person, eller hos et lille mindretal af samfundets medlemmer. Den monarkiske styreform er bedst beskrevet af Thomas Hobbes. Som udgangspunkt ligger suveræniteten i naturtilstanden hos befolkningen, men ved indgåelse af en kontrakt overdrages denne selvbestemmelsesret til den enevældige konge, der herefter repræsenterer folkets vilje (Skirbekk og Gilje, 1987: 264f). Tilsvarende er Montesquieu fortaler for en aristokratisk styreform, hvor det besiddende mindretal alene på grund af arv og titel har en selvskreven ret til at styre samfundet (Montesquieu, 1748: 160). Aristokratiets på forhånd givne ret til at styre (og dermed til en særrepræsentation i parlamentet) krænker folkesuverænitetsprincippet, og der er ingen tvivl om, at denne form for særrepræsentation er udemokratisk. Det vil derfor være udelukket at indføre et førstekammer af denne type.

Det konservative førstekammer er folkevalgt, men ud fra en kvalificeret valgret eller valgbarhed med det formål at beskytte et økonomisk privilegeret mindretal. Begrundelsen for indskrænkningen af valgretten er, at de personer, der betaler flest penge i skat, også skal have mest at sige med hensyn til, hvordan pengene anvendes. Heri ligger underforstået, at hvis det demokratisk valgte andetkammer fik frie hænder, ville der ske en social omfordeling, som ville gå ud over de okonomisk bedst stillede i samfundet. Fra Aristoteles og helt frem til Den franske Revolution havde ordet "demokrati" en negativ betydning, netop fordi folkestyre ville være det samme som de fattiges styre og dermed udgøre en fare for, at adelstanden og aristokratiet ville få frataget deres formue og indflydelse. Det økonomisk velstillede mindretal skal i overensstemmelse hermed værnes mod flertallets tyranni. Et konservativt førstekammer er derfor ikke foreneligt med den demokratiske grundtanke om, at alle, som John Stuart Mill hævdede, har lige politiske rettigheder uanset køn, race, social baggrund og indkomst (Skirbekk og Gilje, 1987: 16f).

Sammensætningen af parlamentets førstekammer kan også ske ved, at udnævnelsen eller opstillingen er forbeholdt personer med særlige uddannelsesmæssige kvalifikationer eller personer, der har nået en vis alder, og som man derfor mener er $\mathrm{i}$ besiddelse af en større erfaring og klogskab (Ross, 1953: 3752). Man kunne benævne denne type det elitistiske førstekammer. Hensigten er at bibringe parlamentet en sagkundskab, som ikke gennem almindelige valg ville være sikker på at blive repræsenteret. Det skulle angiveligt sikre en større grundighed og kvalitet i lovgivningsarbejdet. Det irske Seanad af $1937 \mathrm{er}$ et eksempel på denne type, men også i Belgien har man haft et lignende førstekammer. Forfatningen opstillede her ikke mindre end 21 kategorier af personer, som enten havde beklædt et offentligt embede eller haft en ledende stilling inden for erhvervslivet, og kun disse personer kunne vælges til senatet (Ross, 1953: 3752). En variant af det elitistiske førstekammer er det korporative førstekammer, hvor medlemskabet er forbeholdt repræsentanter for fagforeninger, industri, landbrug, erhversorganisationerne og de højere læreanstalter, som det var tilfældet i Italien under det fascistiske styre (Berlin, 1935: 44ff). 
Både det elitistiske og det korporative førstekammer kan føres tilbage til Platons tanker om en elite af veluddannede herskere. I henhold til Platon kan alene et fătal af befolkningen opnå indsigt i "idèernes verden", hvilket gør dem kvalificerede til at styre samfundet. Samme tankegang finder man hos Lenin, der hævdede, at kun en revolutionær elite ville være i stand til at definere arbejderklassens objektive interesser og derfor skulle stille sig i spidsen for revolutionen (Dahl, 1989: 53ff). Fælles for Platon og Lenin er en opfattelse af, at almindelige mennesker ikke er lige kvalificerede til at styre samfundet og derfor heller ikke har lige ret til at styre.

En sådan holdning er ikke forenelig med det demokratiske lighedsprincip. John Locke udtrykker lighedsprincippet på den måde, at alle mennesker i naturtilstanden er lige og ikke underlagt andres vilje. Dette indebærer, at alle individer har lige politiske og juridiske rettigheder, uanset at de har forskellige evner og kvalifikationer. Men det grundlæggende lighedsprincip kan ikke stå alene (Dahl, 1989: 99). Det er ikke nok, at alle som udgangspunkt har lige rettigheder, og at der tages lige hensyn til alle borgeres interesser ved udformningen af lovene. Man må samtidig slå fast, at enhver bedst selv er i stand til at definere, hvad der er i vedkommendes egen interesse. Heri ligger den afgørende forskel på demokratiet og elitestyret. Da det elitistiske og det korporative førstekammer hviler på en antagelse om, at kun eliten er i besiddelse af den fornødne indsigt til at definere den enkeltes interesser, kan ingen af disse tokammersystemer henregnes til gruppen af demokratiske styreformer.

Den fjerde type forstekammer er det føderale, som oprindelig opstod ved lidt af en tilfældighed. Da den amerikanske forfatning skulle udformes på konventet i Philadelphia i 1787, var hensigten at lave et etkammersystem. Men da man ikke kunne nå til enighed om, hvor mange repræsentanter de enkelte stater skulle have, blev resultatet det nuværende tokammersystem med Senatet som det føderale førstekammer og Repræsentanternes Hus som det folkevalgte andetkammer (Inter-Parliamentary Union, 1962: 4). Det føderale førstekammer adskiller sig således fra de tidligere nævnte typer ved at være sammensat ud fra geografiske kriterier. Parlamentet i en forbundsstat vil som hovedregel efter amerikansk model være delt i to kamre, hvor det ene vælges af folket som helhed, og det andet repræsenterer medlemsstaterne. På lignende måde kan man $\mathrm{i}$ en enhedsstat have et forstekammer for at sikre nærhed og responsivitet i det politiske system. Det sker ved at give amter og kommuner en formel repræsentation i den lovgivende forsamling. Både i Frankrig og Sverige har man haft et sådant førstekammer af føderalt tilsnit.

Det føderale førstekammer ligger klart $\mathrm{i}$ forlængelse af den repræsentative demokratiske teori, idet tokammersystemet sikrer, at de to modsatrettede (men samtidigt ligestillede) hensyn til de enkelte medlemsstater eller kommuner og til fællesskabet tilgodeses. I de fleste tilfælde har hver stat eller kommune lige mange repræsentanter i forstekammeret uanset deres størrelse, hvilket svarer godt til det demokratiske princip om, at alle har én stemme, hvad end deres kvalifikationer er (jf. Dahl, 1989: 109). Det føderale tokammersystem giver desuden delstaterne en beskyttelse mod en alt for stærk centralmagt. 
Denne type førstekammer er derfor i overensstemmelse med såvel folkesuverænitetsprincippet som lighedsprincippet og den geografiske magtdelingslære.

Den sidste type er det demokratiske tokammersystem. Førstekammeret sammensættes her ligesom andetkammeret ved demokratiske valg ud fra lige og almindelig valgret, og der er derfor ikke nogen forskel på de to kamres sammensætning. ${ }^{3}$ Hensigten med det demokratiske tokammersystem er at beskytte borgerne mod en stærk statsmagt og kan ses som en videreførelse af den institutionelle magtdeling mellem parlament, regering og domstole. Når regeringen i overensstemmelse med det parlamentariske princip skal have et flertal bag sig i parlamentet, er der fare for, at den lovgivende og den udøvende magt smelter sammen. Godkendelsen af lovforslagene bliver således en ren formalitet, hvis regeringen sidder på et fast flertal af pladserne i parlamentet. Ved yderligere at dele den lovgivende magt mellem to kamre i parlamentet, sikrer man sig imod, at regeringen får nærmest uindskrænkede magtbeføjelser.

Locke begrunder netop behovet for en deling af den lovgivende og den udøvende magt med henvisning til beskyttelsen af det enkelte individs frihed og ejendom (Friedrich, 1946: 170ff). I sin klassiske begrundelse for behovet for delingen af den lovgivende, den dømmende og den udøvende magt påpeger Montesquieu ligeledes, at enhver, der har nogen form for magt, vil være fristet til at misbruge den. Det gælder både for det enkelte menneske og for institutioner, som er tillagt en magtbeføjelse (Montesquieu, 1748: 157; Malmroth, 1900: 15). John Stuart Mill fører den funktionelle magtdeling mellem lovgivende, dømmende og udøvende magt et trin videre og giver begrundelsen for, at den lovgivende funktion skal deles mellem to institutioner, et førstekammer og et andetkammer. Mill opfatter ikke spørgsmålet om antallet af kamre som afgørende, men mener, at tokammersystemet kan have en vis berettigelse, dog med den helt klare forudsætning, at førstekammeret er sammensat på samme måde som andetkammeret:

\footnotetext{
"The consideration which tells most, in my judgement, in favour of two Chambers is the evil effect produced upon the mind of any holder of power, whether an individual or an assembly, by consciousness of having only themselves to consult. A majority in a single assembly (...) easily becomes despotic and overweening. (...) The same reason which induced the Romans to have two consuls, makes it desirable there should be two Chambers" (John Stuart Mill, 1861: 514).
}

Senest har neoliberalismens mest fremstående repræsentant Friedrich v. Hayek med en tilsvarende begrundelse giort sig til fortaler for et demokratisk tokammersystem (Andersen og Arzouni, 1992: 431). Hayek hævder, at genindførelsen af tokammersystemet vil bringe demokratiet tilbage til sin autentiske form, hvor regeringens magtbeføjelser var begrænsede. Selv om magtdelingen egentlig er et liberalt princip, hvor beskyttelsen af individets rettigheder sættes højest (Friedrich, 1946: 170ff), respekteres samtlige demokratiets grundprincipper i det demokratiske tokammersystem, og denne type førstekammer kunne derfor indføres uden nogen betænkeligheder. 
Figur 1. Oversigt over de forskellige tokammersystemer

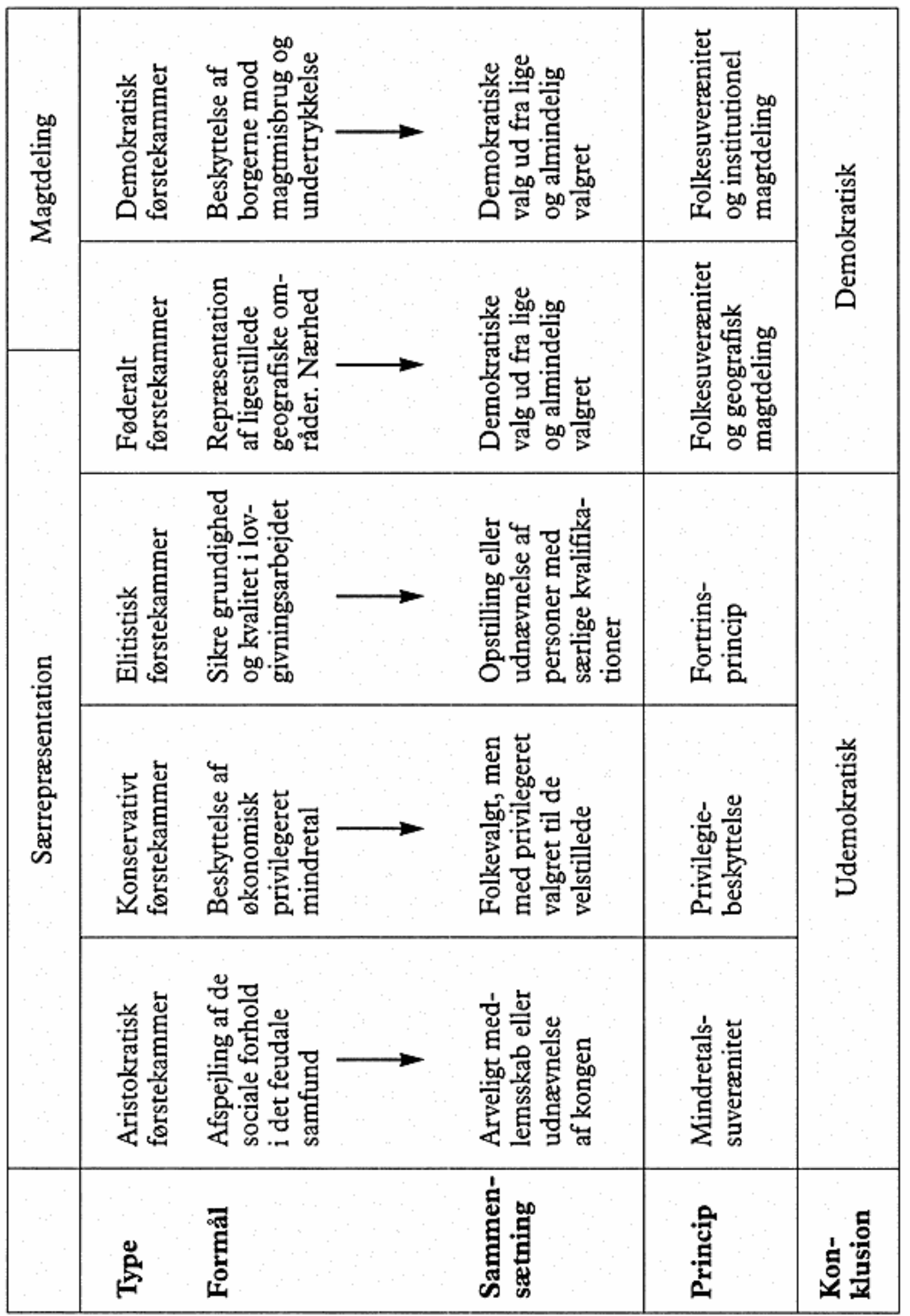




\section{Valgmåden}

Førstekammerets sammensætning bestemmes ikke alene af, hvem der har valgret og hvem der kan vælges, men også af valgmåden, altså hvordan der vælges. Valget kan for det første være enten direkte eller indirekte. Ved det direkte valg har vælgerne den afgørende indflydelse på parlamentets sammensætning. Førstekammerets medlemmer vælges imidlertid ofte indirekte, og den endelige kandidatudvælgelse overlades herved til en snævrere kreds af personer, som selv er udgået af et valg. Begge metoder er helt i tråd med den repræsentative demokratiteori, men den indirekte metode indeholder et element af elitestyre, da hensigten med at lade valget foregå over flere omgange jo er, at man dermed regner med, at kun de bedst kvalificerede bliver valgt. Den indirekte valgmåde făr dermed karakter af en udnævnelse, ligesom i det elitistiske forstekammer, og meningen er tilsvarende at tilgodese hensynet til grundighed og kvalitet i lovgivningen. Det er dog værd at erindre, at også det direkte valg indeholder et indirekte element, idet partiernes opstilling af kandidater meget ofte er afgørende for, hvem der bliver valgt (Andersen, 1951:22).

For det andet kan der enten være tale om et forholdstalsvalg eller et flertalsvalg. Forholdstalsmåden sikrer, at mandaterne fordeles til alle partier i henhold til det stemmeantal, de har opnået ved valget. Modsat forholder det sig med flertalsmetoden, hvor det parti, der har fået flest stemmer i en kreds, vinder mandatet, mens alle stemmer på de øvrige partier reelt går tabt (Vallinder, 1963: 107). Ved at anvende sidstnævnte valgmåde til førstekammeret, kunne man sandsynligvis opnå en større politisk stabilitet og kontinuitet, fordi flertalsmåden som regel giver et topartisystem. Vælgerne tør ganske enkelt ikke stemme på de små partier af frygt for, at deres stemmer skal gå til spilde. Herved risikerer man imidlertid, at store dele af befolkningen ikke får deres synspunkter repræsenteret, og det er uforeneligt med det demokratiske princip om beskyttelse af mindretallenes rettigheder. Forholdstalsvalget må derfor være det mest demokratiske af de to, og det vil være betænkeligt at genindføre et tokammersystem med flertalsvalg til førstekammeret.

For det tredje er valgkredsens storrelse og udformning af meget stor betydning for sammensætningen af førstekammeret. Antallet af valgkredse afhænger af, hvor mange kandidater der skal vælges, og da førstekammeret gerne har færre medlemmer end andetkammeret, er valgkredsene tilsvarende større. Det betyder, at konkurrencen mellem kandidaterne skærpes, og at kun de bedste slipper igennem udvælgelsen. Igen er det hensynet til grundighed og kvalitet $\mathrm{i}$ lovgivningen, der spiller ind. Men jo større valgkredsen er, jo længere afstand er der mellem borgeren og repræsentanten. Ved at lave mindre valgkredse sikrer man omvendt, at vælgerne har bedre mulighed for personligt at kende den kandidat, de stemmer på og dermed kontrollere at den suverænitet, de har overdraget kandidaten, forvaltes på en for dem tilfredsstillende måde. Derfor må mindre valgkredse være at foretrække ud fra et demokratisk synspunkt.

Valgperiode, oploselighed og kompetence

Hensynet til den politiske stabilitet og kontinuitet kan også tilgodeses i tokam- 
mersystemet ved at lade førstekammeret udgøre en tidsmæssig forskydning $\mathrm{i}$ forhold til andetkammeret, eller ved at tillægge førstekammeret kompetence til at bremse eller udskyde andetkammerets initiativer.

\footnotetext{
"This consideration was certainly present in the minds of the statesmen who framed the American federal and state constitutions. The (...) story of Washington pouring the hot tea from his cup into the saucer to cool, thus illustrating the value of the Senate as a body moderating the impulsive tendencies in the House of Representatives, indicates the character of the argument" (Seligman, 1937: 534).
}

Medlemmerne af førstekammeret er således ofte valgt for en længere periode end andetkammerets medlemmer, og man ser ligeledes ofte, at mandaterne til førstekammeret udløber til forskellig tid, mens mandaterne til andetkammeret udløber samtidigt (Andersen, 1951: 22). Herudover er det som regel vanskeligere at opløse førstekammeret, og i nogle tilfælde er førstekammeret valgt for en fast periode. Den længere valgperiode, den successive afgang og den vanskelige opløselighed gør, at førstekammeret kommer til at repræsentere et flere år gammelt billede af vælgernes holdninger, og det antages derfor at lægge en dæmper på udviklingen. Ingen af disse forhold strider mod de demokratiske grundprincipper, så længe valget til førstekammeret afholdes med regelmæssige mellemrum.

De to kamre kan have samme eller forskellig kompetence i en given henseende. Førstekammeret er som regel tillagt en begrænset kompetence, som for eksempel betyder, at det ikke selv kan fremsætte lovforslag, men kun stille ændringsforslag. Man kunne også tænke sig, at førstekammeret havde mulighed for at udskrive folkeafstemning, hvis der opstod uenighed mellem de to kamre. Vigtigst er dog vetoretten. Hvorvidt den absolutte vetoret er demokratisk eller ej, afhænger af førstekammerets sammensætning. Hvis der er tale om et aristokratisk, et konservativt eller et elitistisk forstekammer, så er den absolutte vetoret udemokratisk, fordi førstekammeret herved blokerer for andetkammeret, der repræsenterer det suveræne folks vilje. Det suspensive veto kan have to forskellige udformninger. Enten sådan at andetkammerets beslutning, uanset førstekammerets modstand, er gyldig efter et vist stykke tid, eller sådan at betingelsen for lovens ikrafttræden er, at andetkammeret skal vedtage den samme lov i uændret form efter afholdelse af nyvalg (Ross, 1953: 3758). Da der kun er tale om, at en beslutning udsættes et vist stykke tid, krænker det suspensive veto hverken folkesuverænitetsprincippet, lighedsprincippet eller magtdelingsprincippet, og man kan til og med fremføre, at det suspensive veto giver mindretallet en vis beskyttelse, idet en udsættelse af vedtagelsen af en lov åbner mulighed for, at alle kan komme med kritik og stille ændringsforslag og derigennem blive hørt. Herved sikres endvidere større åbenhed og offentlighed $\mathrm{i}$ beslutningsprocessen. Denne vetoret er derfor helt igennem demokratisk.

\section{Tokammersystemet og demokratiet}

Sammenfattende kan man sige, at det vil være udelukket at indføre et tokammersystem med aristokratiske, konservative eller elitistiske elementer, idet dis- 
se alle strider mod de demokratiske grundprincipper. Det kan kun komme på tale at indføre enten et føderalt eller et demokratisk førstekammer, der er sammensat ud fra lige og almindelig valgret og valgbarhed ved direkte forholdstalsvalg i mindre kredse. Hvis formålet med at vende tilbage til tokammersystemet er at sikre stabilitet og kontinuitet i lovgivningen, kan man indføre længere valgperioder, successiv afgang og gøre det vanskeligt at opløse førstekammeret. Det vil i alle tilfælde være fuldt demokratisk. Med hensyn til kompetencen kan førstekammeret tillægges enten absolut eller suspensivt veto, da både førstekammeret og andetkammeret jo er valgt på demokratisk vis, og således begge kan gøre krav på at repræsentere det suveræne folk.

\section{Etkammersystemet}

Selv om det er muligt at genindføre tokammersystemet, er det imidlertid ikke sikkert, at det også er nødvendigt. Man må derfor se nærmere på, om funktionsproblemerne eventuelt kunne løses indenfor det nuværende etkammersystem. Men ligesom der findes forskellige typer tokammersystemer, er etkammersystemet ikke bare et parlament med kun et enkelt kammer. Man kan således skelne mellem et reelt og et formelt etkammersystem.

Det reelle etkammersystem blev indført med de franske forfatninger allerede i 1791 og 1793, men afskaffedes igen få år senere. Luxembourg indførte i 1868 et sådant etkammersystem, og $\mathrm{i}$ årene efter 1 . verdenskrig fik også de nye stater Estland, Letland og Litauen et parlament med kun et enkelt kammer. Herudover kendes denne type kun fra de lande, der har afskaffet tokammersystemet. De er samtidig alle kendetegnet ved at være mindre, befolkningsmæssigt ensartede stater. Det reelle etkammersystem ses generelt som folkestyrets fuldendelse, dels fordi det bygger på folkesuverænitetsprincippet og lighedsgrundsætningen, og dels fordi det ikke levner plads til nogen form for særrepræsentation til bestemte befolkningsgrupper.

Det formelle etkammersystem er i virkeligheden en mellemting mellem etog tokammersystemet. Det norske parlament, Stortinget, deler sig efter valget $i$ en ovre og en nedre afdeling, Odelstinget og Lagtinget. Lovforslagene behandles først i Odelstinget og sendes derefter til Lagtinget, som enten kan ændre eller forkaste forslaget (Andersson, 1963: 86). Det norske system blev forbillede for den forfatning, der indførtes på Island i 1944, og også Finland har et formelt etkammersystem. Ethvert lovforslag skal foruden den almindelige behandling i parlamentet også godkendes i Store Udvalg, for herigennem at sikre, at forslagene bliver behandlet omhyggeligt af rigsdagens bedste kræfter (Rasmussen, 1972: 126). Dette system kombinerer fordelene fra både etkammer- og tokammersystemet. Demokratiets grundprincipper respekteres gennem den lige og almindelige valgret, og man opnår en vis grundighed og kvalitet ved den dobbelte behandling af lovforslagene. Det formelle etkammersystem minder således på mange måder om det demokratiske førstekammer. Forskellen består $i$, at begge de to afdelinger i det formelle etkammersystem er valgt ved det samme valg, og derfor også opløses samtidig, medens det demokratiske førstekammer typisk har længere valgperiode end andetkammeret og 
er vanskeligere at opløse. Derfor giver det demokratiske tokammersystem alt andet lige større politisk stabilitet og kontinuitet end det formelle etkammersystem.

\section{Etkammersystemet og funktionsproblemerne}

Ved at ændre de politiske spilleregler i det nuværende reelle etkammersystem ville man sandsynligvis kunne opnå nogle af de samme fordele, som tokammersystemet og det formelle etkammersystem byder på. Med henblik på at opnå større stabilitet og kontinuitet kunne man styrke regeringens stilling over for parlamentet ved at indføre konstruktivt mistillidsvotum og positiv parlamentarisme. Som reglerne er nu i det danske etkammersystem, kan regeringen væltes, blot et flertal i parlamentet stemmer imod den. Men hvis der fandtes et krav om, at regeringen kun kunne afsættes, hvis partierne samtidig kunne pege på en ny regering, ville det givetvis afværge en del forsøg på at vælte regeringen. Tilsvarende ville et krav om, at en regering kun kan dannes, hvis den har et flertal bag sig, have samme virkning. Faste valgperioder har også været på tale, og endelig kunne en forhøjelse af spærregrænsen måske give et mere stabilt partisystem (Petersen, 1992: 20ff). Hvor de tre førstnæunte forslag er fuldt demokratiske, er en forhøjelse af spærregrænsen mere tvivlsom, idet man herved udelukker eventuelle mindretal fra at blive repræsenteret i parlamentet.

Problemet med manglende grundighed og kvalitet i form af uovervejede beslutninger kan også gøres mindre inden for de nuværende institutionelle rammer. Ved at indføre en minimumsgrænse for, hvor hurtigt et lovforslag kan passere Folketinget, eller et krav om kvalificeret flertal på eksempelvis to tredjedele af medlemmerne ved visse vigtige love, ville man tvinge partierne til forhandlinger og kompromis. Naturligvis måtte sådanne regler følges af muligheden for at dispensere ved særligt hastende love (Petersen, 1992: 20ff). Et sådant krav om kvalificeret flertal er ikke nødvendigvis mindre demokratisk end den almindelige flertalsregel, da man ikke ud fra den demokratiske teori entydigt kan afgøre, hvilken afstemningsprocedure, der er mest demokratisk (Dahl, 1989: 135ff). En regel om generel udsættelse af lovens ikrafttræden er også en mulighed for at sikre større grundighed.

\section{Skal tokammersystemet genindføres?}

For mange vil en genindførelse af tokammersystemet umiddelbart lyde som et demokratisk tilbageslag. Som en tilbagevenden til fortidens privilegier og særrepræsentation for enkelte befolkningsgrupper. Men tokammersystemet behøver ikke at være udemokratisk. Det afhænger af, hvad formålet med førstekammeret er, hvordan det sammensættes, og hvilken kompetence man tillægger det i forhold til andetkammeret.

Hvis formålet er at sikre stabilitet og kontinuitet, kan man enten indføre et demokratisk førstekammer, valgt ud fra lige og almindelig valgret ved direkte valg i mindre kredse, eller et formelt etkammersystem, hvor parlamentet vælges ved ét valg og herefter deler sig i to afdelinger. Men i det formelle etkammersystem opløses begge parlamentets kamre samtidigt, og man opnår derfor 
Figur 2. Losninger på de aktuelle politiske problemer

\begin{tabular}{|c|c|c|}
\hline \multirow{2}{*}{ MÅL } & \multicolumn{2}{|c|}{ MIDDEL } \\
\hline & Tokammersystem & Etkammersystem \\
\hline $\begin{array}{l}\text { Stabilitet, } \\
\text { kontinuitet }\end{array}$ & $\begin{array}{l}\text { - længere valgperioder } \\
\text { - vanskelig opløselighed } \\
\text { - flertalsvalg i } \\
\text { enkeltmandskredse } \\
\text { - færre medlemmer } \\
\text { - successiv afgang } \\
\text { - selvvalg af medlemmer }\end{array}$ & $\begin{array}{l}\text { - positiv } \\
\text { - paralamentarisme } \\
\text { - konstruktivt } \\
\text { mistillidsvotum } \\
\text { - faste valgperioder } \\
\text { - forhøjelse af } \\
\text { spærregrænsen }\end{array}$ \\
\hline $\begin{array}{l}\text { Grundighed, } \\
\text { kvalitet }\end{array}$ & $\begin{array}{l}\text { - dobbelt behandling } \\
\text { - udpegelse af særligt } \\
\text { kvalificerede personer } \\
\text { - indirekte valg } \\
\text { - større valgkredse } \\
\text { - absolut eller } \\
\text { suspensivt veto }\end{array}$ & $\begin{array}{l}\text { - faste udvalg i } \\
\text { parlamentet } \\
\text { - kommissions- } \\
\text { behandling } \\
\text { - minimums tidsfrist } \\
\text { for behandling af } \\
\text { lovforslag } \\
\text { - kvalificeret flertal } \\
\text { - generel udsættelse } \\
\text { af ikrafttrædelse }\end{array}$ \\
\hline $\begin{array}{l}\text { Offentlighed, } \\
\text { åbenhed }\end{array}$ & $\begin{array}{l}\text { - oversendelse af } \\
\text { lovforslagene } \\
\text { mellem kamrene }\end{array}$ & $\begin{array}{l}\text { - offentlige høringer } \\
\text { og åbne møder }\end{array}$ \\
\hline $\begin{array}{l}\text { Nærhed, } \\
\text { responsitivitet }\end{array}$ & $\begin{array}{l}\text { - særrepræsentation } \\
\text { for lokale interesser }\end{array}$ & $\begin{array}{l}\text { - lokale interesse- } \\
\text { organisationer } \\
\text { inddrages }\end{array}$ \\
\hline
\end{tabular}

ikke større politisk stabilitet end i det nuværende reelle etkammersystem. På den anden side er det demokratiske tokammersystem heller ikke nogen god løsning. Selv om førstekammeret er valgt for en længere periode med vanskelig opløselighed, vil der efter al sandsynlighed være nogenlunde samme partimæssige flertal i begge kamre, og så er førstekammeret reelt overflødigt. I stedet kunne man ændre de politiske spilleregler i det eksisterende etkammersystem ved at indføre faste valgperioder, positiv parlamentarisme og konstruktivt mistillidsvotum. Det vil formentlig være mere effektivt end et at genindføre tokammersystemet.

Det formelle etkammersystem og det demokratiske førstekammer er ligeledes en mulighed, hvis hensigten med en grundlovsændring er at opnå større grundighed og kvalitet $\mathrm{i}$ lovgivningen. Men den eneste fordel vil $\mathrm{i}$ givet fald være, at lovforslagene undergives en dobbelt behandling. Det gælder derfor som før, at man lige så godt kunne ændre det nuværende etkammersystem 
fremfor at genindføre tokammersystemet. Man kunne eksempelvis kræve kvalificeret flertal til vedtagelse af vigtige love eller fastsætte en tidsmæssig begrænsning på, hvor hurtigt et lovforslag kan behandles af Folketinget. Hvis man, som Henning Christophersen har foreslået det, lader førstekammeret bestå af personer med en særlig indsigt eller uddannelse for at sikre en højere kvalitet, er der ikke længere tale om et demokratisk, men et elitistisk førstekammer, og det er i strid med de demokratiske grundprincipper.

Tokammersystemet kunne endvidere være med til at sikre større åbenhed og offentlighed omkring lovgivningen, som fremført af Niels Helveg Petersen. I etkammersystemet træffes mange af de politiske beslutninger i parlamentets faste udvalg, hvortil medlemmerne er udpeget af deres partigrupper. Det gør det sværere for vælgerne at kontrollere beslutningsprocessen og dermed efterfølgende stille politikerne til ansvar for deres handlinger. Med et direkte valgt EU-førstekammer kunne problemet muligvis overvindes. Men det er mere sandsynligt, at der også under et førstekammer vil blive nedsat udvalg, hvis møder ikke er åbne for offentligheden. Det er ganske enkelt en forudsætning for at nå de nødvendige kompromisløsninger, at partierne har mulighed for at forhandle og indgå aftaler bag lukkede døre. Desuden er idéen uigennemførlig alene af den grund, at det ville være umuligt at afgøre, om førstekammeret eller andetkammeret har kompetencen i en konkret sag, da næsten alle politikområder har både nationale og internationale aspekter.

Endelig kunne man genindføre tokamersystemet for at opnå større nærhed og responsivitet. Et førstekammer med særrepræsentation for amter og kommuner kunne i den forbindelse være en udmærket idé, og et sådant tokammersystem af føderalt tilsnit ville være i fuld overensstemmelse med de demokratiske grundprincipper. Men partihensyn vejer oftest tungere end hensynet til den lokale valgkreds for det enkelte parlamentsmedlem, og det er derfor tvivlsomt, om et føderalt førstekammer ville virke efter hensigten. Det kunne let vise sig at blive en kopi af andetkammeret, og det ville dermed miste sin betydning. Desuden er Danmark ikke delt af væsentlige geografiske konfliktliner, som det er tilfældet i de lande, der har et føderalt tokammersystem. Hertil kommer, at de lokale hensyn i forvejen varetages $i$ etkammersystemet, hvor Kommunernes Landsforening ofte er blevet beskyldt for at fungere som en slags førstekammer.

Alt $\mathrm{i}$ alt må det derfor konkluderes, at man med fordel kunne ændre det nuværende etkammersystem fremfor at genindføre tokammersystemet, uanset hvilken type førstekammer der er tale om.

\section{Noter}

1. Betegnelsen forstekammer anvendes på dansk, svensk og hollandsk om det kammer, der som hovedregel enten er sammensat ud fra en begranset valgret eller ud fra geografiske kriterier, medens andetkammeret hviler på lige og almindelig valgret. I England og Frankrig bruges betegnelserne omvendt (Wheare, 1968: 132f). 
2. Den her anvendte opdeling er tilnærmet efter Forfatningskommissionens Betankning fra 1953, hvor Alf Ross skelner mellem et aristokratisk herrehus, et konservativt overhus, et demokratisk forstekammer og det foderative tokammersystem (Ross, 1953: 3748).

3. Hos Alf Ross er det demokratiske forstekammer udgăet af helt eller tilnærmelsesvis samme valgret som andetkammeret. En højere valgretsalder til førstekammeret, indirekte valgmảde og storre kredse er săledes ifolge Ross demokratisk (Ross, 1953: 3747f).

\section{Litteratur}

Andersen, Poul (1951). "Folkereprasentationens deling i to kamre", Den liberale Venstre-Almanak, 18. árgang, pp. 21-24.

Andersen, Steffen og Christopher Arzrouni (1992). "Marked og frihed. F.A.Hayek", Politica, 24. árgang, nr. 4, pp. 421-434.

Andersson, Leif (1963). "En eller tvă kamrar?”, pp. 84-106 i Pär-Erik Back (red.), Modern demokrati, Lund: Gleerups.

Berlin, Knud (1935). Et- eller tokammer, København: Nyt Nordisk Forlag.

Berlingske Tidende

Christensen, Jergen Grønnegaard (1992). "Institutionelle sider af forfatningsdiskussionen", pp. 23-41 i N. H. Petersen (red.), Pá sporet af den nye grundlov, København: Gyldendal.

Christophersen, Henning (1989). Tanker om Dammark i det mye Europa, København: Bersens Forlag.

Dahl, Robert A. (1989). Democracy and its critics, New Haven: Yale University Press.

Friedrich, Carl J. (1946). Constitutional Government and Democracy, Boston: Ginn and Co.

Inter-Parliamentary Union (1962). Parliaments. A comparative study on the structure and functioning of representatice institutions, London: Cassel and Company.

Malmroth, Carl (1900). Kamranas inbördes ställning i stater med tớkammarsystem, Lund: Lunds Universitet.

Mill, John Stuart (1861). "Considerations on Representative Government", pp. 371-578 i J.S. Mill, Essays on Politics and Society, volume XIX, Toronto: University of Toronto Press.

Montesquieu (1748). The Spirit of the Laws. Cambridge texts in the history of political thought, Cambridge: Cambridge University Press.

Petersen, Niels Helveg (1992). "Nye demokratiske spilleregler", i N.H.Petersen (red.): Pá sporet af den mye grundlov, København: Gyldendal.

Rasmussen, Erik (1972). Komparativ politik 2, 2.udgave, København: Gyldendal.

Ross, Alf (1946). Hoorfor demokrati?', 1. udgave, København: Munksgaard.

Ross, Alf (1953). "Memorandum af maj 1946 vedrerende tokammersystemets udformning i demokratiske stater", Betenkning afgitut af Forfaningskommissionen af 1946, Rigsdagstidende 1952-53, tillæg A, bind II.

Seligman, E. (1937). Encyclopaedia of the Social Sciences, volume 2, New York: Macmillan.

Skirbekk, Gunnar og Niels Gilje (1987). Filosofihistorie 1, Oslo: Universitetsforlaget.

Vallinder, Torbjörn (1963). "Majoritetsval eller proportionella val?", pp. 107-139 i Pär-Erik Back (red.), Modern demokrati, Lund: Gleerups.

Wheare, K.C. (1968). Legislatures, 2.edition, Oxford: Oxford University Press. 
2. Den her anvendte opdeling er tilnærmet efter Forfatningskommissionens Betankning fra 1953, hvor Alf Ross skelner mellem et aristokratisk herrehus, et konservativt overhus, et demokratisk forstekammer og det foderative tokammersystem (Ross, 1953: 3748).

3. Hos Alf Ross er det demokratiske forstekammer udgăet af helt eller tilnærmelsesvis samme valgret som andetkammeret. En højere valgretsalder til førstekammeret, indirekte valgmảde og storre kredse er săledes ifolge Ross demokratisk (Ross, 1953: 3747f).

\section{Litteratur}

Andersen, Poul (1951). "Folkereprasentationens deling i to kamre", Den liberale Venstre-Almanak, 18. árgang, pp. 21-24.

Andersen, Steffen og Christopher Arzrouni (1992). "Marked og frihed. F.A.Hayek", Politica, 24. árgang, nr. 4, pp. 421-434.

Andersson, Leif (1963). "En eller tvă kamrar?”, pp. 84-106 i Pär-Erik Back (red.), Modern demokrati, Lund: Gleerups.

Berlin, Knud (1935). Et- eller tokammer, København: Nyt Nordisk Forlag.

Berlingske Tidende

Christensen, Jergen Grønnegaard (1992). "Institutionelle sider af forfatningsdiskussionen", pp. 23-41 i N. H. Petersen (red.), Pá sporet af den nye grundlov, København: Gyldendal.

Christophersen, Henning (1989). Tanker om Dammark i det mye Europa, København: Bersens Forlag.

Dahl, Robert A. (1989). Democracy and its critics, New Haven: Yale University Press.

Friedrich, Carl J. (1946). Constitutional Government and Democracy, Boston: Ginn and Co.

Inter-Parliamentary Union (1962). Parliaments. A comparative study on the structure and functioning of representatice institutions, London: Cassel and Company.

Malmroth, Carl (1900). Kamranas inbördes ställning i stater med tớkammarsystem, Lund: Lunds Universitet.

Mill, John Stuart (1861). "Considerations on Representative Government", pp. 371-578 i J.S. Mill, Essays on Politics and Society, volume XIX, Toronto: University of Toronto Press.

Montesquieu (1748). The Spirit of the Laws. Cambridge texts in the history of political thought, Cambridge: Cambridge University Press.

Petersen, Niels Helveg (1992). "Nye demokratiske spilleregler", i N.H.Petersen (red.): Pá sporet af den mye grundlov, København: Gyldendal.

Rasmussen, Erik (1972). Komparativ politik 2, 2.udgave, København: Gyldendal.

Ross, Alf (1946). Hoorfor demokrati?', 1. udgave, København: Munksgaard.

Ross, Alf (1953). "Memorandum af maj 1946 vedrerende tokammersystemets udformning i demokratiske stater", Betenkning afgitut af Forfaningskommissionen af 1946, Rigsdagstidende 1952-53, tillæg A, bind II.

Seligman, E. (1937). Encyclopaedia of the Social Sciences, volume 2, New York: Macmillan.

Skirbekk, Gunnar og Niels Gilje (1987). Filosofihistorie 1, Oslo: Universitetsforlaget.

Vallinder, Torbjörn (1963). "Majoritetsval eller proportionella val?", pp. 107-139 i Pär-Erik Back (red.), Modern demokrati, Lund: Gleerups.

Wheare, K.C. (1968). Legislatures, 2.edition, Oxford: Oxford University Press. 